\title{
Jan Zelenka, Beneficium et feudum. Podoba a proměny lenního institutu, Praha 2016 (= Práce Historického ústavu AV ČR A: Monographia, 66), ss. 228
}

Jan Zelenka se v předchozích letech profiloval zejména jako jeden z organizátorů setkání $\mathrm{k}$ dějinám dvorů, $\mathrm{k}$ nimž také přispíval svými referáty. Rovněž tak se vyslovoval k problému vztahu mezi českými zeměmi a říší v obrazu pramenů 12. století. Zároveň se ale stával stále více zřetelným i jeho zájem o lenní institut, a to zejména ve vztahu $\mathrm{k}$ diskusím o tzv. středoevropském modelu vedeným $\mathrm{v}$ předchozím decenniu. Kniha, kterou nyní předkládá, je upravenou verzí jeho disertační práce obhájené na ÚČD FF UK v roce 2013 a vyrovnává se onou třetí skupinou otázek, které Zelenku dosud zajímaly.

I když je autorovým primárním cílem přispět do diskuse ke společenskému uspořádání a právních poměrech $\mathrm{v}$ českých zemích 10.-13. století, $\mathrm{k}$ tématu přistupuje s důvodnou oklikou. Jeho práce se tak rozpadá do dvou vzájemně provázaných celků. $\mathrm{V}$ rámci první hlavy totiž Zelenka nejprve analyzuje prameny vzniklé v hranicích pěti saských biskupství Míšeň, Naumburg, Hildesheim, Halberstadt a Merseburg. Sleduje zejména několik základních kategorií, jež nejsou bez významu ani v domácí diskusi (udělené statky, dědičnost, povinnosti, vztah lén a zástav, prekárie, uvedení v léno a závazky, obraz lenního poměru v narativních pramenech) (21-52). Nashromážděné doklady, jejichž počet mnohonásobně převyšuje objem pramenů české a moravské provenience, ukazují velkou pestrost a neurčitost terminologie, jež odráží nejasnost obsahů, které mají definovat. Dokládají, jak závažnou roli sehrával zejména sociální kontext, do něhož byl daný právní institut zasazen, stejně jako jeho potenciální funkce. (Paralely bychom snadno našli i v jiných, vzdálenějších prostředích.) Ostatně odpoutáme-li se od 
předsudků získaných četbou učebnic, nebude se nám i bez těchto analýz rozdíl mezi emfyteuzí a lénem jevit tak zřetelný. Svůj postup Zelenka následně zasazuje prostřednictvím hutného historiografického exkurzu (53-62) do proudu novějšího bádání, jež někdy starší, dosti schematický obraz pevných a jednoznačně definovaných struktur rozbíjí ve prospěch méně zřetelných a později vzniknuvších společensko-právních praktik.

Tyto úvahy jsou autorovi následně východiskem pro další „návrat k pramenům “, tentokrát při výpravě za koncepty pravého léna, ius ministerialium, přenášení lén a jejich mnohonásobného udělení, případně při pátrání po úloze žen v lenní držbě (63-88). Ty jenom potvrzují pružný charakter lenního institutu $\mathrm{v}$ různých situacích, kdy mohly, ale nemusely lenního pána a obleněné oddělovat značné sociální bariéry, kdy předmětem lenní povinnosti mohla, ale také nemusela být vojenská služba a konkrétní léna sice nemusela být podle tenoru listiny udělována dědičně, avšak v praxi dědičně udělována byla.

Na vztahu mezi Jindřichem Lvem a jeho mocnými vazaly (89-101) konečně Zelenka ukazuje, že ani zdánlivě jasný pojem věrnosti nemusel být prost interpretačních nejasností. Mohl snadno vést ke konfliktu mezi vévodou a jeho mocnými vazaly, kdy obě strany zkoušely posunout hranice možného ve svůj prospěch, aby bud' posílily právo pána žádat, nebo ubránily své právo riskovat ve službách pána, aniž by jejich majetky doznaly př́ilišné újmy. Zelenka upozorňuje, že se panovníci (a spolu s nimi i další prríslušníci knížecí vrstvy v říši) snažili rovněž ctít majetkovou integritu držav svých vazalů, a proto se jejich itinerář opíral kromě vlastního fisku nanejvýše o centra ř́šsské církve.

Připraviv si půdu pro návrat do prostředí přemyslovského knížectví, Zelenka nejprve opět mapuje terén vymezený starší historiografií ohledně ukotvení tamní společenské elity a ukazuje, že mantinely hřiště, mezi kterými se bádání dodnes pohybuje, byly vymezeny nejpozději na konci 19. století (107-114). Je sympatické, že nám připomíná, jakým zásadním způsobem Dušan Třeštík obohatil stávající diskurs o sadu nových otázek a řešení, aniž by zapomínal na to, jak budoucí diskusi zatížil svou snahou o pointované vyjádření. Následně se věnuje vývoji názorů na význam lenního institutu v českém prostředí. Zaměřuje se zejména na to, jakým způsobem $s$ pojmem beneficium pracuje L. Jan a problematizuje jeho zacházení s výsledky staršího i novějšího bádání (W. Weizsäcker, H. Mitteis a B. Kasten).

Stručné, avšak hutné dějiny problému skýtají v knize dobrý odrazový můstek pro analýzu pramenů české provenience do konce doby přemyslovské. Zelenka se zde zaměřje zejména na rozklíčování významu termínů beneficium, beneficiarius 
a suppa, či feudum, přičemž již ze stručného výčtu vyplývá blízkost feuda a purkrechtu, př́padně se potvrzuje prostupnost suppy a suppana s označením sociální prŕslušnosti, jak na to upozornil např. L. Jan (121-130). Tyto úvahy autor dále rozvijí, když se zaměřuje na výklad obsahu pojmu beneficium (131-134). Nejprve ukazuje, že jako beneficiarii nebyli označováni leníci, dále dokládá, že hereditas a beneficium či feudum nebyly navzájem se vylučující pojmy, avšak že použití termínu hereditas signalizovalo (podobně jako v Sasku) dědičnost daného majetku bez ohledu na to, jednalo-li se o držbu, nebo vlastnictví. Snesené doklady zároveň ukazují, že předivo vzájemných vazeb lze v českém prostředí oproti prostředí saskému charakterizovat $s$ menší jistotou a přesností, nebot soubor pramenů je neporovnatelný svou hustotou. Propůjčení v léno Zelenka chápe i v souladu předchozích analýz provedených na saském materiálu paralelně k udělení purkrechtu, jehož prostřednictvím se precizoval vzájemný vztah mezi stranami.

Následně se vrací k důležitému pojmu beneficiarius, které údajně jedni považují obecně za úředníky pobírající část knížecích př́ijmů, zatímco jej druzí chápou jako reprezentanty veřejné moci sídlící v centrech a vybavené $\mathrm{k}$ výkonu své služby beneficii, tj. jakýmisi kvasilény. Autor nejprve putuje proti proudu času, pátrá po kořenech současných konceptů ve starší zahraniční literatuře a ukazuje na nosnost rozlišení mezi na úřad vázaným beneficiem a doživotním lénem, jak jej zavedla již starší literatura (140-146). Umožňuje mu dále uvažovat nad tím, který koncept je trefnější pro postižení poměrů v českých zemích doby přemyslovské - zde se mu mj. i pro „krátkost lenních řetězcü“, stejně jako pro paralely, které lze vést mezi franskými a českými normativními ustanoveními jeví jako vhodnější koncept beneficia vázaného na výkon služby (147-154).

Předchozí úvahy byly ovšem pro Zelenku opět pouze odrazovým můstkem $\mathrm{k}$ rozboru postavení elit přemyslovského knížectví. Zde vidí autor právem jako klíčové problém vztahu mezi elitami a knížetem, podíl elit na moci a konečně problém jejich majetkového vybavení. Zelenka je právem skeptický k úvahám, které protežují vybití, respektive asimilaci knížecích nepřemyslovských elit v 10. století a nevidí důvod, proč neumožnit Přemyslovcům sledovat různé strategie $\mathrm{v}$ různých př́ípadech. (Ambivalentnost vztahu mezi knížetem a elitami dále dokládá notoricky známými citáty z Kosmy (ale také z dalších autorů), jež ukazují moc elit a panovníka jako vzájemně provázanou - tento závěr ostatně, soudím, obecně vyplývá z relativní slabosti (raně středověkých) elit, jež potřebovaly určité krystalizační jádro a koordinační centrum, aby si udržely vládu nad společností, a tím knížecí dvůr bezpochyby mohl být.) Tím se utvářel systém dynamické 
rovnováhy, kdy na jedné straně stanul kníže disponující beneficii, jež byla bez věrných beneficiářu bezcenná, na straně druhé elity, soupeřící o udělení některého z omezeného počtu těchto beneficií, jak to již naznačila starší historiografie. Majetek, zděděný i propůjčený, byl součástí hry o moc. (Pokud jde o ten zděděný, Zelenka zde právem usmiřuje názory obou táborů, kdy vyhrocené formulace mnohdy zakryly shodu v obsahu, a nijak neproblematizuje existenci pozemkového vlastnictví v rukou českých raně středověkých elit.) Své vývody uzavírá obligátním rozborem ustanovení Statut Konráda Oty, jež, myslím oprávněně, chápe jako tečku za bouřlivým obdobím, a nikoli jako klíč $\mathrm{k}$ definici hereditates ve 12.-14. století. Sympatické je i to, že se autor zamýšlí nejenom nad existujícími prameny, ale i nad zprávami, jež bychom sice očekávaly, ale tyto chybí. To mu umožňuje zformulovat stručný závěr, který je i historiografickým zamyšlením nad př́činami sporu. Ukazuje na problematičnost jazyka Dušana Třeštíka, který rád provokoval a sklouzával k zjednodušujícím tvrzením, která se mnohdy obracela proti jeho vlastním představám (zejména obraz dirigistického státu vs. obraz silných a sebevědomých Moravanů či Bohemanů). Právem problematizuje i to, jakým způsobem Třeštík pracoval s pojmem „vlastnictvi“ ve středověku - rozlišuje totiž na rozdíl od něho mezi abstrakcí představenou středověkým vzdělancem Kosmou, a možným vnímáním vlastnictví mezi elitami i nižšími sociálními vrstvami, k němuž máme jenom velmi omezený př́stup. Kritikou však Zelenka nešetří ani na závěry zformulované zejména L. Janem, a zaměřuje se právem zejména na retrogresivní metodu, o níž se primárně opřel, případně ukazuje na vzájemné protimluvy (R. Antonín). Konečně upozorňuje na údajně nedbalé užívání zahraniční literatury a jí zformulovaných konceptů.

Celkově zanechává kniha svou věcností příznivý dojem, zároveň však před čtenářem stále více odhaluje základní problém celé starší diskuse, a to doposavad (při rozsahu látky a i intenzitě zájmu paradoxní) ne zcela dostatečné analytické zvládnutí matérie 13. století. Částečnou odpověd’ přinášejí studie L. Jana či D. Janiše, nicméně ty se primárně soustředují na sledování vývoje zemských institucí na Moravě. Podobné texty pro Čechy chybí, byt naopak nové perspektivy nabídly sídelně historicky orientované prríspěvky J. Klápště nebo T. Velimského, jichž se nedostává na Moravě. Rovněž tak se ukazuje, že je obtížné vážit jednotlivá svědectví, protože mnohé texty $\mathrm{v}$ rámci diskuse nenabízejí odpovědi na zcela základní otázky, a to kolik takových svědectví je a jak jsou rozmístěna v čase a prostoru. Tím ovšem zůstává celá diskuse uzavřená a omezuje se na úzký okruh specialistů. Stř́ílivým jazykem psaná práce Jana Zelenky tu pootevírá dveře a přináší nové 
podněty, ale i ona se zastavuje před r. 1200. Doufejme tedy, že vyústí v rozsáhlejší badatelský projekt, který se kromě zdůraznění nejistot a paradoxů, jež odpovídají více sociálně historicky a méně právně historicky střiženému pojetí, pokusí nabídnout celému souboru otázek pevnější kontury.

Doc. David Kalhous, PhD.,

Ústav pomocných věd historických a archivnictví

Filozofická Fakulta

Masarykova Univerzita

ul. Gorkého 63/14, 602-00 Brno

david.kalhous@oeaw.ac.at 